\title{
23. K-Ar AGES OF DEEP-SEA BASALTS, INDIAN OCEAN, LEG 25, DEEP SEA DRILLING PROJECT
}

\author{
Edwin H. McKee, U. S. Geological Survey, Menlo Park, California
}

\section{INTRODUCTION}

Samples of basalt from near the bottom of two drill holes (Leg 25, Sites 245 and 248) in the western Indian Ocean were dated by $\mathrm{K}-\mathrm{Ar}$ methods. The dating provided information about the age of the basement or oceanic crust (Site 248) and of a diabasic intrusion (Site 245).

\section{GEOLOGIC CONTROL}

Basalt was recovered from the bottom few meters of the two holes beneath about 400 meters of sediment. At Site 245 , the sedimentary sequence is 389 meters thick and ranges back in time to early Paleocene. Two varieties of basalt, a glassy and a diabasic type, were recovered from this hole. The coarse-grained (diabasic) variety is probably from an intrusive body that we anticipated could be considerably younger than the basement or glassy basalt. Site 248 penetrated 434 meters of sediment with an age range from probable late Paleocene to Pleistocene. The sample taken is representative of the 3.6-meter core of homogeneous porphyritic basalt considered to be basement at this site.

\section{SAMPLES}

Three specimens of basalt from Leg 25 were considered for dating by the K-Ar method. The specimen from Site 239 was eliminated because it contains volcanic glass, now largely devitrified, which would probably yield an unreliable age. The other two (Sites 245 and 248) are holocrystalline and should retain radiogenically produced $\mathrm{Ar}^{40}$ at lattice sites of $\mathrm{K}$-bearing mineral phases. One of the samples selected (Site 248) contains enough large plagioclase phenocrysts to permit separation of this mineral; a whole-rock sample was used for dating the other sample (Site 245).

\section{ANALYTICAL PROCEDURE}

Analyses of both specimens were carried out in the laboratories of the U. S. Geological Survey in Menlo Park, California using the same procedures. The whole-rock sample from Site 245 was prepared by cutting a 5-g cube from the center of the drill core. Two parts of the cube, each weighing about $3 / 4 \mathrm{~g}$, were powdered and used for potassium analysis; the remainder (about $3.5 \mathrm{~g}$ ) was fused in the argon extraction. The sample from Site 248, from which plagioclase was dated, was prepared by crushing and sieving between 60 and 100 mesh. Then, mineral components were separated by heavy liquid and magnetic separation procedures. The argon analyses were carried out using standard isotope-dilution techniques. Mass analyses were made with a Nier-type 60 -in. radius $60^{\circ}$ sector mass spectrometer operated in the static mode. The potassium analyses were obtained by flame photometer using a lithium internal standard. Two potassium analyses were made on the whole-rock sample (Sample 245-19) and three on the plagioclase mineral separate (Sample 248-15). The decay constants used for $\mathrm{K}^{40}$ are $\lambda \mathrm{e}=0.585 \times 10^{-10} \mathrm{yr}-1$ and $\lambda \beta=4.72 \times 10^{-10} \mathrm{yr}^{-1}$, and the atomic abundance of $\mathrm{K}^{40}$ is $1.19 \times 10^{-4}$ mole/mole.

The precision of the date, shown as the \pm value, is the analytical uncertainty in the measurement of radiogenic argon 40 and potassium in the sample. The value is determined on the basis of experience with duplicate analyses in the Menlo Park laboratories. In a general way, samples that contain a low percentage of radiogenicallyproduced argon (large percent of atmospheric argon) have a higher analytical uncertainty. The estimated error for the two samples, both with less than 15 percent radiogenic $\mathrm{Ar}^{40}$, is about 10 percent of the age.

\section{AGES}

Sample 248-15: Fresh-looking intergranular porphyritic basalt. The groundmass is plagioclase, clinopyroxene, magnetite, and chlorophaeite; phenocrysts are clinopyroxene, plagioclase, and olivine. Plagioclase phenocrysts as long as $5 \mathrm{~mm}$ were separated and dated. The age is $72.3 \pm 7$ m.y. (Table 1 ).

Sample 245-19: Fresh-looking intergranular mediumgrained basalt. It contains plagioclase, augite, magnetite, and a trace of glass and chlorite. Whole rock dated. The age is $27.0 \pm 3$ m.y. (Table 1).

\section{DISCUSSION}

The $72.3 \pm 7$ m.y. date from the sample at Site 248 seems to be a valid age for the basaltic basement in this region. Sediments above it are dated on fossil evidence as probable late Paleocene, and at least 6 meters of sedimentary core directly above the basalt was not recovered, so that the lowest part of the sedimentary record is missing. The age of about 72 m.y. is also the same, within analytical uncertainty, as basalts from Madagascar as reported by $\mathrm{H}$. Besairie (personal commun. to T. L. Vallier, 1973). Correlation of basalt volcanism in this broad region in the western part of the Indian Ocean on the basis of radiometric ages may offer a firm base to work from in developing times of rifting and plate motions.

The date of $27 \pm 3$ m.y. from Site 245 supports speculation, based on rock texture and contact relationships, that the rock is intrusive. If this is true, the date indicates that basic rocks were being emplaced as much as about 45 m.y. after formation of the crust in this region. 
E. MCKEE

TABLE 1

K-Ar Dating, Leg 25 Samples

\begin{tabular}{|c|c|c|c|c|c|}
\hline Sample & $\begin{array}{c}\text { Material } \\
\text { Dated }\end{array}$ & $\begin{array}{l}\mathrm{K}_{2} \mathrm{O} \\
(\%)\end{array}$ & $\begin{array}{c}\mathrm{Ar}^{40} \mathrm{rad} \\
(\mathrm{mole} / \mathrm{gm})\end{array}$ & $\frac{\mathrm{Ar}^{40} \mathrm{rad}}{\mathrm{Ar}^{40} \text { total }}$ & $\begin{array}{l}\text { Apparent } \\
\text { Age (m.y.) }\end{array}$ \\
\hline $248-15$ & Plagioclase & $\begin{array}{l}0.121 \\
0.121 \\
0.123\end{array}$ & $1.325 \times 10^{-11}$ & 8.1 & $72.3 \pm 7$ \\
\hline $245-19$ & Whole rock & $\begin{array}{l}0.480 \\
0.484\end{array}$ & $1.935 \times 10^{-11}$ & 12.8 & $27.0 \pm 3$ \\
\hline
\end{tabular}

